\title{
Cutting Height of Mombasa Grass Under Silvopastoral and Monoculture Systems
}

\author{
M. O. D. Rodrigues ${ }^{1}$, A. C. dos Santos ${ }^{1}$, M. O. D. Rodrigues ${ }^{1}$, O. Silveira Junior ${ }^{2}$, L. B. T. de Oliveira ${ }^{3}$ \\ \& R. L. de L. Leite ${ }^{2}$ \\ ${ }^{1}$ Universidade Federal do Tocantins, Brazil \\ ${ }^{2}$ Instituto Federal do Tocantins, Brazil \\ ${ }^{3}$ Universidade Federal do Maranhão, Brazil \\ Correspondence: L. B. T. de Oliveira, Universidade Federal do Maranhão, Chapadinha, BR 222, Brazil. E-mail: \\ tavernyzoot@yahoo.com.br
}

Received: October 7, 2018

Accepted: February 9, $2019 \quad$ Online Published: April 15, 2019

doi:10.5539/jas.v11n5p433

URL: https://doi.org/10.5539/jas.v11n5p433

\begin{abstract}
This study aimed to evaluate the production of Mombasa grass cultivation under two different systems: monoculture and silvopastoral, with heights of $70,80,90$, and $100 \mathrm{~cm}$. Two seasons were evaluated: rainy period (December to March) and rain/drought transition (March to June). The variables evaluated were: total dry mass (TDM), dry mass (DM) of the morphological components, number of tillers, efficiency of nitrogen use, DM content, number of harvest cycles and cutting intervals. The experimental design was a randomized block design with five replications. The monoculture system presented the highest yields of TDM, number of tillers and DM of the morphological components in the two evaluated periods. The main variable affected by shading was the number of tillers per area, which directly affects all variables linked to production. In addition to the type of system, the time of the year also influenced the production of DM of the grass. The evaluation of grass productivity in silvopastoral system evidenced that the plant tends to respond differently to cutting management when compared to the monoculture system. In the monoculture system, the recommended height for greater TDM yield and better leaf/stem ratio in the rainy period and the rainy/drought transition period was $80 \mathrm{~cm}$, maintaining the residue height at $40 \mathrm{~cm}$. As for SSP, cutting height of $70 \mathrm{~cm}$ presented the highest TDM and leaf/stem ratio for the two evaluated periods, maintaining the residue height at $40 \mathrm{~cm}$.
\end{abstract}

Keywords: management, tiller, shading

\section{Introduction}

The success of silvopastoral systems implantation is mainly related to the choice of forage species. It is important that the chosen species presents high adaptive capacity to the restriction of luminosity and presents high nutritional value and productivity, attending the production objectives (Almeida et al., 2015).

Grasses adjust to the stress generated by the shading, modifying their morphological components (leaf, stem, and senescent material) and altering its proportions in the pasture. Thus, when trying to adapt, the plant modifies the aerial part/root relation, starting to invest more in photoassimilates for the aerial part as an adjustment to increase the efficiency of light uptake, by increasing the effective leaf area, adjusting the leaf angulation, and increasing leaf area index for each tiller (Gobbi et al., 2009).

The morphological changes occurring in grasses in the adjustment of the light absorption are adaptations to the silvopastoral system, making management in this type of system totally different from the management adopted for a grass managed in full sun. Height is one of the main criteria adopted for the management of pasture areas in relation to animal traffic of a certain area.

In monoculture this criterion has been a reference for the management of any type of pasture. According to Garcez-Neto et al. (2010), pasture management practices cultivated in full sunlight generally do not support grasslands grown in shaded systems due to the microclimatic variations that influence the growth dynamics of the grass, generating totally different structural modifications of grass grown in full sun and requiring management practices that fit the forage development capacity of the shaded system. Perennial pastures characteristics depend 
not only on the maintenance and addition of nutrients in the soil by fertilization, but also on the use of management techniques that are specific to the system (Brossad \& Barcellos, 2005).

The grasses of the genus Megathyrsus maximus, cv Mombasa, have shown production in silvopastoral systems similar to pasture in full sun, proving to be a grass with high capacity to shading adaptation, reaching high levels of dry mass production in shady systems (Oliveira et al., 2017).

The growth rate of Mombasa grass in an intercropped system occurs more slowly due to modifications imposed by the arboreal component that interferes with dry mass availability, which decreases as shading intensifies. There is a negative correlation between shading and grass productivity due to the low quality and quantity of the light that enters the lower layer of the canopy (Oliveira et al., 2018).

The slower growth rate in the silvopastoral systems is also reported by Santos et al. (2018), who found that shading significantly affected the dry mass content of forage under shade due to higher proportion of leaves and higher live:dead ratio in the grass. According to Gobbi et al. (2011), another factor that reduces the dry mass content of the grass in a shading system is the modification in leaf anatomy; even with an increase of the specific leaf area there is a decrease in the mass density of the forage, with a reduction of sclerenchyma cells and the thickness of the palisade parenchyma.

Therefore, this study aimed to compare how the management heights: 70, 80, 90, and $100 \mathrm{~cm}$ affect the productivity patterns of Megathyrsus maximus cv Mombasa in a silvopastoral system composed of native trees and conventional pasture in order to avoid management generalization.

\section{Material and Methods}

The experimental area is located at the School of Veterinary and Animal Science, Federal University of Tocantins (EMVZ-UFT), Brazil. The predominant soil of the region is Quartzipsamment soil. According to Köpen (1948), the region presents AW (humid hot) climate, with average temperature of $28{ }^{\circ} \mathrm{C}$ and average annually rainfall of $1800 \mathrm{~mm}$. Two production systems were evaluated, one characterized by the intercropping of the pasture with native forest (silvopastoral system, SSP) and traditional monoculture. The experimental area of each evaluated system was $0.4 \mathrm{ha}$, where each system was allocated individually. The areas were managed under four management heights in each system in order to determine the ideal height of the management of both systems. The evaluated heights were: 70, 80, 90, and $100 \mathrm{~cm}$ with five replications within each system. In order to evaluate the effect of the system type and the height of Mombasa grass in each environment, a $4 \times 2$ factorial design was used (four heights and two systems) in randomized blocks with five replications each, totaling 40 parcels.

The adjustment of the shading of each area was determined by measuring illuminance (Lux), using a luxmeter (LD 200 Instrutherm). A total of 50 points were measured. Light readings were performed between 6:00 a.m. and 1:00 p.m., comparing with the measurements of the area of full sun (FS). From these measurements the percentage of shading of each area was calculated, being: $100-$ (Measurement in SSP/Measurement in SP) $\times 100$.

The area in which the experiment was conducted has a history of use since 2009 , where the area was thinned to reach a level of shading of nearly $25 \%$. The area is composed of grasses of the genus Megathyrsus maximus cv. Mombasa. Soil correction was conducted in October 2014 with the application of $2 \mathrm{Mg} \mathrm{ha}^{-1}$ in both systems in order to raise calcium levels to $2 \mathrm{cmol}_{\mathrm{c}} \mathrm{dm}^{3}$ in the $0-20 \mathrm{~cm}$ layer. Soil fertilization occurred in November 2014 with application of $300 \mathrm{~kg} \mathrm{ha}^{-1}$ year $^{-1}$ nitrogen in the form of ammonium sulfate for both areas, 57.48 and $57.63 \mathrm{~kg} \mathrm{ha}^{-1}$ year ${ }^{-1}$ of $\mathrm{P}_{2} \mathrm{O}_{5}$ in the form of superphosphate, $240 \mathrm{~kg} \mathrm{ha}^{-1}$ year $^{-1}$ of $\mathrm{K}_{2} \mathrm{O}$ (distributed throughout the crop cycle) as potassium chloride based on soil analysis (Table 1).

Table 1. Soil chemical characteristics in the $0-20 \mathrm{~cm}$ layer

\begin{tabular}{lllllllllll}
\hline Systems & $\mathrm{pH}$ & $\mathrm{MO}$ & $\mathrm{P}$ & $\mathrm{K}$ & $\mathrm{Ca}$ & $\mathrm{Mg}$ & $\mathrm{Al}$ & $\mathrm{H}+\mathrm{Al}$ & $\mathrm{SB}$ & $\mathrm{V}$ \\
\hline & & $-----\mathrm{g} \mathrm{kg}^{-1}-----$ & $--------\mathrm{mg} \mathrm{dm}^{-3}$ & --------- & $\mathrm{cmol}_{\mathrm{c}} \mathrm{dm}^{-3}$ & & & $\%$ \\
Silvopastoral & 4.5 & 2.04 & 0.82 & 2 & 0.0036 & 0.0033 & 0.0018 & 0.45 & 2.0 & 2.6 \\
Monoculture & 4.7 & 4.76 & 0.79 & 1 & 0.0040 & 0.0030 & 0.0063 & 0.46 & 1.0 & 2.03 \\
\hline
\end{tabular}

Evaluation started in November 2014, where the first cycle of evaluations was used only to standardize the treatments; only productivity was evaluated and the demographic evaluation of the tiller community was started. Thus, the evaluation of all variables started in December 2014 and extended until June 2015. The evaluation periods were divided into a rainy season, which began on December 21, 2014 and ended on March 20, 2015, and a 
rainy/drought transition season, which lasted from March 21 to June 21. The precipitation data of the evaluated period are present in Figure 1.

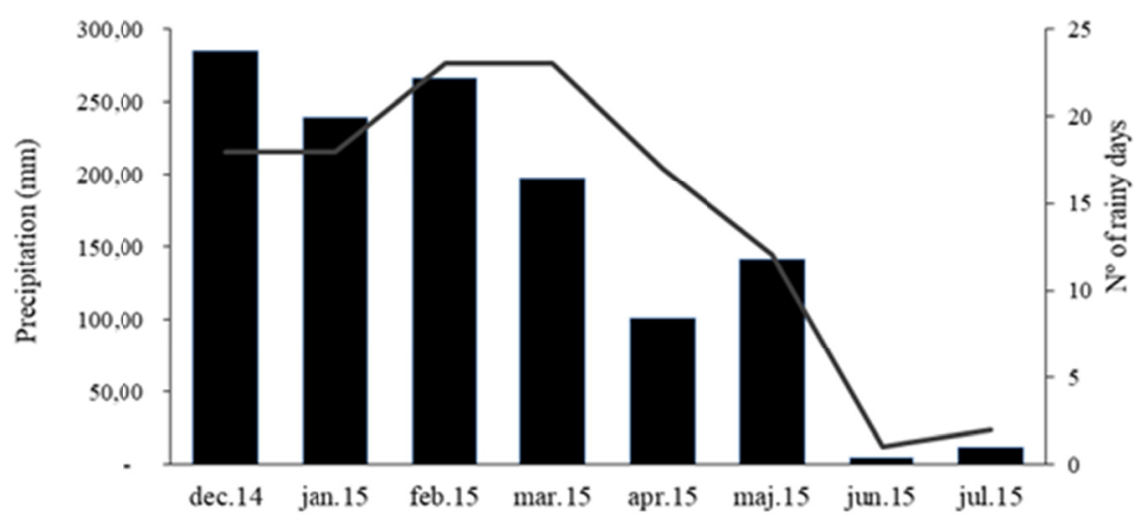

Figure 1. Precipitation data of the experimental evaluation period

The treatments were monitored so that the cut of each height was performed at the expected height. To determine the mean height of each treatment, 20 points were measured using a ruler in each plot, allowing a maximum variation of $5 \%$ between the heights specified for each treatment (Palhano et al., 2005).

Grass samples were collected in each plot of the experimental unit for both periods. Residual mass was collected at $40 \mathrm{~cm}$ from the soil surface for all treatments. An area of $1.0 \mathrm{~m}^{2}(1 \times 1 \mathrm{~m})$ was sampled for forage quantification. The subsamples were separated from the samples, and the morphological components were separated. Thereafter, these components were oven dried at $65^{\circ} \mathrm{C}$ until constant weight for further analysis.

The evaluated agronomic characteristics of the grass were: total dry mass (TDM) and of the morphological components leaf blade, stem + leaf sheath and dead material, leaf/stem ratio, number of cuts per period, cutting intervals, and number of tillers.

The data were submitted to analysis of variance and the F test and compared by the Duncan test using the SAS statistical software. Regression analysis was applied by means of quadratic or linear regression equations ( $p>0.05)$ to evaluate the effect of cutting heights on the productive characteristics of the Mombasa grass.

\section{Results and Discussion}

The cutting intervals of both systems were influenced by the height of the tree, the time of year and the intensity of shading (Table 2). Therefore, the rest period tends to increase as the cutting height of the grass increases in both systems and at different times of the year. The resting period presented a linear decreasing characteristic in the rainy period. In the monoculture, the average increase was 4.5 days per cycle for each $10 \mathrm{~cm}$ increased in the cutting height of the grasses. As for the SSP system, there was an increase of 5.5 days in the rest period for every 10 $\mathrm{cm}$ that increased at the cutting height. This was due to a stress factor related to shading and competition for luminosity, nutrients, and water, which directly influenced the growth process of the grass, causing the plant grown in the monoculture system to have a higher growth rate when compared to the SSP system (Oliveira et al., 2017).

In the transition period rainyldrought another factor that is directly connected in the increase of the cut interval was the amount of rainfall of the evaluated period due to the decrease of precipitation in the period. There was an increase in the number of days of the resting period for all heights regardless of the evaluated system. The rainy/drought transition period had the same tendency as in the rainy season, but with an increase in the days of rest period of 6.95 days for each $10 \mathrm{~cm}$ that increases in the height of the forage in that period. 
Table 2. Cutting interval, number of cuts and total dry matter (TDM) of Mombasa grass in silvopastoral and monoculture systems in different times of the year

\begin{tabular}{|c|c|c|c|c|c|c|c|}
\hline \multirow{2}{*}{ Variable } & \multirow{2}{*}{ System } & \multirow{2}{*}{ Average } & \multirow{2}{*}{ Regression } & \multirow{2}{*}{$\mathrm{R}^{2}$} & \multirow{2}{*}{$\mathrm{CV}$} & \multicolumn{2}{|c|}{ Significance } \\
\hline & & & & & & System & Height \\
\hline \multirow{6}{*}{$\mathrm{P}^{\mathrm{o}}$ rest (days) } & Rainy & & & & \multirow{3}{*}{0} & \multirow{3}{*}{0.001} & \multirow{3}{*}{0.001} \\
\hline & SSP & $23 \mathrm{a}$ & $Y=-23.40+0.550 x$ & 0.96 & & & \\
\hline & Monoculture & $21 \mathrm{~b}$ & $Y=-17.12+0.455 x$ & 0.98 & & & \\
\hline & \multicolumn{4}{|l|}{ Rainy/drought } & \multirow{3}{*}{0} & \multirow{3}{*}{0.001} & \multirow{3}{*}{0.001} \\
\hline & SSP & $29 \mathrm{~b}$ & $Y=-29.650+0.690 x$ & 0.96 & & & \\
\hline & Monoculture & $33 \mathrm{a}$ & $Y=-26.376+0.695 x$ & 0.96 & & & \\
\hline \multirow{6}{*}{ Number of cuts } & Rainy & & & & \multirow{3}{*}{0} & \multirow{3}{*}{0.001} & \multirow{3}{*}{0.001} \\
\hline & SSP & $4.5 \mathrm{~b}$ & $\mathrm{Y}=13.00-0.1 \mathrm{x}$ & 0.99 & & & \\
\hline & Monoculture & $4.7 \mathrm{a}$ & $Y=15.00-0.13 x$ & 0.96 & & & \\
\hline & \multicolumn{4}{|l|}{ Rainy/drought } & \multirow{3}{*}{0} & \multirow{3}{*}{0.001} & \multirow{3}{*}{0.001} \\
\hline & SSP & $1.7 \mathrm{~b}$ & $Y=4.300-0.030 x$ & 0.6 & & & \\
\hline & Monoculture & $2.5 \mathrm{a}$ & $\mathrm{Y}=5.90-0.040 \mathrm{x}$ & 0.8 & & & \\
\hline \multirow{6}{*}{ TDM (t/ha) } & Rainy & & & & \multirow{3}{*}{9.84} & \multirow{3}{*}{0.001} & \multirow{3}{*}{0.001} \\
\hline & SSP & $5.495 \mathrm{~b}$ & $\mathrm{Y}=7927.89-28.620 \mathrm{x}$ & 0.17 & & & \\
\hline & Monoculture & $10.962 \mathrm{a}$ & $Y=15827.25-57.238 x$ & 0.4 & & & \\
\hline & \multicolumn{4}{|l|}{ Rainy/drought } & \multirow{3}{*}{12.13} & \multirow{3}{*}{0.001} & \multirow{3}{*}{0.001} \\
\hline & SSP & $3.214 \mathrm{~b}$ & $Y=2145.76+12.57 x$ & 0.51 & & & \\
\hline & Monoculture & 7.763 a & $Y=-2909.03+125.56 x$ & 0.67 & & & \\
\hline
\end{tabular}

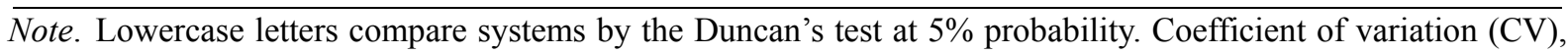
Total dry mass (MST).

The number of cuts (Table 2) is directly related to the growth rate of the grass to reach a certain harvest height and to the number of days to reach the recommended height. In this sense, the growth rate of the grass in the silvopasture system was more slowly due to modifications imposed by the arboreal component, which interfered with dry mass availability. The DM decreased as the shading intensified, presenting negative correlation between shade and grass productivity due to the amount of light entering the lower canopy stratum (Santos et al., 2018). The number of cuts in the rainy season linearly decreased for both systems, with one cutting occurring for each $10 \mathrm{~cm}$ that rises at the height of the SSP system, whereas for the monoculture system the reduction is 1.3 cuts for every 10 $\mathrm{cm}$ of height increase (Table 2).

In the rainy/drought transition period the number of cuts presented similarity between heights when compared within each system, with an increasing linear tendency. In SSP, for each increase of $10 \mathrm{~cm}$ in the cut height, there was an increased of 0.3 cycles, while in monoculture this increase was 0.4 cycles for every $10 \mathrm{~cm}$. Even with longer resting periods, the forage of the monoculture system presented better vigor and persistence at the end of the transition period, exceeding SSP in the number of cuts (Table 2). This behavior was due to the growth rate of the grass managed outside the influence of trees, which tends to be higher than grasses intercropped with trees. The numbers and intervals of cuts are directly influenced by edaphoclimatic factors, which resulted in the variation of the amount of cuts in the two periods. The decrease in precipitation affected the growth of the grass in the transition period, reducing the regrowth capacity for this period (Barbosa et al., 2007). 
Table 3. Production characteristics, number of tillers and agronomic efficiency index of Mombasa grass in silvopastoral and monoculture systems at different times of the year

\begin{tabular}{|c|c|c|c|c|c|c|c|}
\hline \multirow{2}{*}{ Variable } & \multirow{2}{*}{ System } & \multirow{2}{*}{ Average } & \multirow{2}{*}{ Regression } & \multirow{2}{*}{$\mathrm{R}^{2}$} & \multirow{2}{*}{$\mathrm{CV}$} & \multicolumn{2}{|c|}{ Significance } \\
\hline & & & & & & System & Height \\
\hline \multirow{6}{*}{$\mathrm{DM} /$ cycle/ha } & Rainy & & & & \multirow{3}{*}{11.12} & \multirow{3}{*}{0.001} & \multirow{3}{*}{0.001} \\
\hline & SSP & $1287.3 \mathrm{~b}$ & $Y=-736.02+23.804 x$ & 0.57 & & & \\
\hline & Monoculture & $2491.8 \mathrm{a}$ & $Y=-2138.05+54.47 x$ & 0.92 & & & \\
\hline & \multicolumn{4}{|l|}{ Rainy/drought } & & & \\
\hline & SSP & $1939.9 \mathrm{~b}$ & $Y=-1987.337+46.20$ & 0.56 & \multirow{2}{*}{14.42} & \multirow{2}{*}{0.001} & \multirow{2}{*}{0.001} \\
\hline & Monoculture & $3310.5 \mathrm{a}$ & $Y=-5596.45+104.78 x$ & 0.93 & & & \\
\hline \multirow{6}{*}{$\mathrm{N}^{\mathrm{o}}$ of tiller } & Rainy & & & & \multirow{3}{*}{16.47} & \multirow{3}{*}{0.001} & \multirow{3}{*}{0.0072} \\
\hline & SSP & $118 \mathrm{~b}$ & $\mathrm{Y}=221.7-1.2107 \mathrm{x}$ & 0.17 & & & \\
\hline & Monoculture & $260 \mathrm{a}$ & $Y=1655.97-32.2 x+0.182 x^{2}$ & 0.42 & & & \\
\hline & \multicolumn{4}{|l|}{ Rainy/drought } & & & \\
\hline & SSP & $126 \mathrm{~b}$ & $\mathrm{Y}=232.36-1.25 \mathrm{x}$ & 0.84 & \multirow{2}{*}{13.87} & \multirow{2}{*}{0.001} & \multirow{2}{*}{0.001} \\
\hline & Monoculture & $230 \mathrm{a}$ & $Y=2163.66-42.54 x+0.228 x^{2}$ & 0.8 & & & \\
\hline \multirow{6}{*}{ L/S Ratio } & Rainy & & & & \multirow{3}{*}{59.15} & \multirow{3}{*}{0.1} & \multirow{3}{*}{0.001} \\
\hline & SSP & $82.81 \mathrm{~b}$ & $\mathrm{Y}=82.81$ & 0.17 & & & \\
\hline & Monoculture & $229.26 \mathrm{a}$ & $Y=680.51-6.663 x$ & 0.79 & & & \\
\hline & \multicolumn{4}{|l|}{ Rainy/drought } & \multirow{3}{*}{67.23} & \multirow{3}{*}{0.1} & \multirow{3}{*}{0.001} \\
\hline & SSP & $23.88 \mathrm{a}$ & $Y=906.10-19.632 x+0.107 x^{2}$ & 0.55 & & & \\
\hline & Monoculture & $34.38 \mathrm{a}$ & $\mathrm{Y}=201.405-1.964 \mathrm{x}$ & 0.52 & & & \\
\hline
\end{tabular}

Note. Lowercase letters compare systems in rows by the Duncan's test at $5 \%$ probability. Coefficient of variation (CV), Leaf/stem ratio (L/S), dry mass (MS).

The production of DM in SSP was lower than the monoculture system for both evaluated periods (Table 2). The amount of DM available in the monoculture system was 50\% higher than the SSP when comparing to productivity between cutting heights. This difference in productivity is mainly related to the amount of light that the grass receives, which is affected by the forest that competes directly for the quantity and quality of light. It also affects the growth rate and the rate of appearance of new tillers. Thus, DS production of a given grass is related to its leaf area index and the number of plants per area.

According to Andrade et al. (2003), the cultivar Mombasa is a forage that shows good productivity in intercropped systems, as long as it maintains good soil fertility and can reduce competition for light, nutrients and water, not affecting their productive performance.

The TDM production available in the rainy period presented the same decreasing linear behavior. Ii the SSP system, there was a decreased of $286.2 \mathrm{~kg}$ of DM for each $10 \mathrm{~cm}$ increase in height, while for monoculture the decrease in production for the same management strategies was $572.38 \mathrm{~kg}$ of DM for each $10 \mathrm{~cm}$ increase (Table 2).

This similarity between the levels of DM in the two systems for the rainy season showed the compensation that occurs as the plant reaches higher heights. Within a given period, where the same management conditions are given, forage quality is with the requirements of use, allowing the diversification in the form and period of harvest (Table 2). Regardless of the cutting height per period, there was similar productivity in the rainy period. However, the quality of DM varied due to modifications of the leaf/stem morphological components. This relation tended to decrease as the height increased, occurring greater accumulation of stem and senescent material.

Production of TDM were influenced both by the time and cutting height in the rainy/drought transition period for both systems, which showed the difference in grass growth in the transition period, avoiding the generalization of heights management for systems evaluated as for distinct times within the same year. According to Paciullo et al. (2011), crops under influence of silviculture directly affect the pasture characteristics, the density of tillers, DM accumulation, and also the nutritional composition.

Unlike the rainy period, in the transition period the increase of TDM production linearly increased. In the rainy/drought transition period, stem and senescent material accumulation compensated the decrease in precipitation. There were increases of 125.7 and $1255.6 \mathrm{~kg}$ of TDM for each $10 \mathrm{~cm}$ that was elevated from the 
height of cut in SSP and monoculture, respectively (Table 2). It was observed that with changes in precipitation, lower heights tended to decrease the productivity in both systems (Table 2).

The amount of dry matter per cycle (DM cycle) harvested in the rainy period was inversely proportional to TDM, presenting linear increase. The MS cycle tends to increase with the increase in cutting height due to the higher accumulation of forage per centimeter grown and also the decrease of water content in the plant. As the height increases there is an increase in the structural development of the plant. Production of DM per cycle differed between the SSP and monoculture systems. The monoculture system presented higher DM production per cycle in relation to SSP, which had a production of approximately $50 \%$ of DM in the rainy period (Table 4).

The production of MS per cycle in the rainy period (Table 4) in SSP increased $238.04 \mathrm{~kg}$ of DM in every $10 \mathrm{~cm}$ of cutting height increase. As for monoculture, the increase of DM per cycle is in the range of $544.7 \mathrm{~kg}$ MS for every $10 \mathrm{~cm}$ increase in cutting height. The amount of DM per cycle was directly influenced by the productive system, where SSP affected grass productivity due to the presence of tress, which competes for light, nutrients, and water, decreasing the tillering rate, tiller lifespan (Paciullo et al., 2008), and regrowth rate (Andrade et al., 2004).

The productive patterns of the rainy/drought transition period regarding the production of DM per cycle was similar to the rainy period, where the production of DM per cycle increased linearly as the cutting height increased. There were higher yields in the monoculture system when compared to SSP (Table 3).

The rainy/drought transition period presented the highest DM productivity per cycle regardless the cutting height and the evaluated system. Due to the decrease of rainfall the plant tends to modify its structure to adjust to the period, taking more time to reach a certain height, which could have affected plant growth in the period. The productivity variation at different times of the year at the same height or cutting intervals evidences the need for studies to better understand the management of pasture for each period in order to optimize the use of forage, reducing losses and maximizing the harvest efficiency (Santos et al., 2004).

The highest productivity rates of DM were 462 and $1047.8 \mathrm{~kg}$ per cycle for SSP and monoculture, respectively, in the rainy/drought transition period. However, it does not mean that the grass is more productive, since this period have higher cutting interval (Table 2), directly reflecting the amount of TDM available in the period (Table 3).

The number of tillers per $\mathrm{m}^{2}$ is directly related to forage production, in which the number of plants, leaf area index (LAI) and number of leaves reflect the productivity of the system. The monoculture system differed statistically from the SSP system in relation to the number of tillers $/ \mathrm{m}^{2}$ (Table 4), with a larger number of tillers in monoculture regardless the cutting height in the rainy season, reaching $50 \%$ of the number of tillers in relation to SSP. The number of tillers is directly related to forage DM production, which is strongly influenced by natural shading, since it modifies the red: far-red ratio of the incident radiation, directly affecting the quality and quantity of light (Oliveira et al., 2017), altering the density of tillers per area in shady environments and affecting the appearance of new tillers (Paciullo et al., 2008). The smallest number of plants in SSP is directly related to the quantity and quality of the luminosity that enters the forest, where the patterns of growth and appearance of tillers in this type of system also affects the lifespan of the plant.

In the rainy period the number of tillers per $\mathrm{m}^{2}$ in SSP linearly decreased, decreasing around 12 tillers for each 10 $\mathrm{cm}$ that was elevated at the grass cutting height. In the monoculture system, number of tillers per $\mathrm{m}^{2}$ presented a quadratic effect with a lower number of tillers per $\mathrm{m}^{2}$ at the height of $88.46 \mathrm{~cm}$. The highest number of tillers per $\mathrm{m}^{2}$ found in the lower heights is related to the amount of luminosity. The growth patterns and appearance of tillers in this type of system also affects the life span of the plant.

The variable number of tillers per $\mathrm{m}^{2}$ (Table 3 ) in the rainy/drought transition period presented interaction. The monoculture and SSP systems differed statistically, with the highest numbers of tillers per $\mathrm{m}^{2}$ in the monoculture system, regardless of the time of year. SSP showed a linear decreasing effect, reducing the number of tillers per $\mathrm{m}^{2}$ to 12.5 tillers for each $10 \mathrm{~cm}$ that was decreased from the cutting height, whereas for the monoculture system the effect was quadratic with the minimum production of tillers at the height of $93 \mathrm{~cm}$ (Table 3 ).

The L/S ratio in the rainy period in SSP had no effect and the cutting heights did not differ for this characteristic. For the monoculture system, the L/S ratio was linearly decrease around $66.6 \mathrm{~kg}$ of DM of leaf for each $1 \mathrm{~kg}$ of DM of stem (Table 3). The L/S ratio in the rainy/drought transition period in SSP had a quadratic effect with a point of lower L/S ratio at the height of $91.7 \mathrm{~cm}$. As for the monoculture system in that period, the $\mathrm{F} / \mathrm{C}$ ratio linearly decreased $19 \mathrm{~kg}$ of MS of leaf for each $1 \mathrm{~kg}$ of DM of stem.

Production of DML per cycle in SSP linearly increased $187.5 \mathrm{~kg}$ of DML for each $10 \mathrm{~cm}$ of cutting grass height. In the monoculture system, the DML accumulation values were in the range of $389 \mathrm{~kg}$ of DML for every $10 \mathrm{~cm}$ added in cutting height in the rainy season. In the rainy/drought transition period both systems linearly increased; the SSP 
system increased $363.2 \mathrm{~kg}$ of DML for every $10 \mathrm{~cm}$ more height in the grass managed in that system. The accumulation in the monoculture system increased $572.3 \mathrm{~kg}$ of DML (Table 4). SSP tends to affect the production of these components due to a series of factors related to competition for luminosity, water and nutrients. This leads the plant to modify its growth patterns in function of adjusting to the stress caused by the arboreal system, changing its architecture, number of leaves, and also the life span and appearance of tillers. Modification of photosynthetically active radiation by shading affects the photosynthetic pathway and the translocation of photoassimilates of tropical grasses, which are C4-cycle type (Dias-Filho, 2002). The main factor limiting the productivity of pasture intercropped with trees is the level of shading adopted that may compromise the growth of the forage (Belesky, 2005).

Table 4. Productivity of the morphological components: leaves, stems, senescent material and \% MS of Mombasa grass in silvopastoral and monoculture systems at different times of the year

\begin{tabular}{|c|c|c|c|c|c|c|c|}
\hline \multirow{2}{*}{ Variable } & \multirow{2}{*}{ System } & \multirow{2}{*}{ Average } & \multirow{2}{*}{ Regression } & \multirow{2}{*}{$\mathrm{R}^{2}$} & \multirow{2}{*}{$\mathrm{CV}$} & \multicolumn{2}{|c|}{ Significance } \\
\hline & & & & & & System & Height \\
\hline \multirow{6}{*}{ DML (kg/ha/cycle) } & Rainy & & & & \multirow{3}{*}{10.57} & \multirow{3}{*}{0.001} & \multirow{3}{*}{0.001} \\
\hline & SSP & $1159.43 \mathrm{~b}$ & $Y=-434.57+18.753 x$ & 0.56 & & & \\
\hline & Monoculture & $2171.62 \mathrm{a}$ & $Y=-1135.08+38.90 x$ & 0.89 & & & \\
\hline & \multicolumn{4}{|l|}{ Rainy/drought } & & & \\
\hline & SSP & $1733.4 \mathrm{~b}$ & $Y=-1354.405+36.32$ & 0.53 & \multirow{2}{*}{16.12} & \multirow{2}{*}{0.001} & \multirow{2}{*}{0.001} \\
\hline & Monoculture & $2577 \mathrm{a}$ & $Y=-2287.879+57.23 x$ & 0.87 & & & \\
\hline \multirow{6}{*}{ DMS (kg/ha/cycle) } & Rainy & & & & & & \\
\hline & SSP & $110.19 \mathrm{~b}$ & $Y=-279.91+4.59 x$ & 0.51 & \multirow{2}{*}{34} & \multirow{2}{*}{0.001} & \multirow{2}{*}{0.001} \\
\hline & Monoculture & $234.11 \mathrm{a}$ & $Y=-706.99+11.072 x$ & 0.42 & & & \\
\hline & \multicolumn{4}{|l|}{ Rainy/drought } & & & \\
\hline & SSP & $157.09 \mathrm{~b}$ & $Y=5785.33-151.24 x+1.00 x^{2}$ & 0.71 & \multirow{2}{*}{53.5} & \multirow{2}{*}{0.0004} & \multirow{2}{*}{0.001} \\
\hline & Monoculture & $320.06 \mathrm{a}$ & $Y=-449.124+7.131$ & 0.52 & & & \\
\hline \multirow{6}{*}{ DSM (kg/ha/cycle) } & Rainy & & & & & & \\
\hline & SSP & $17.69 \mathrm{~b}$ & $Y=-21.54+0.461 x$ & 0.2 & \multirow{2}{*}{81} & \multirow{2}{*}{0.1} & \multirow{2}{*}{0.0023} \\
\hline & Monoculture & $86.15 \mathrm{a}$ & $Y=-295.99+4.46 x$ & 0.45 & & & \\
\hline & \multicolumn{4}{|l|}{ Rainy/drought } & & & \\
\hline & SSP & $49.36 \mathrm{~b}$ & $Y=-183.81+2.743$ & 0.28 & \multirow{2}{*}{31.5} & \multirow{2}{*}{0.1} & \multirow{2}{*}{0.001} \\
\hline & Monoculture & $413.4 \mathrm{a}$ & $Y=-1954.89+27.86 x$ & 0.86 & & & \\
\hline
\end{tabular}

Note. Lowercase letters compare systems in rows by the Duncan's test at 5\% probability. Dry mass of leaf (DML), dry mass of stalk (DMS), Dry senescent mass (DSM), Coefficient of variation (CV).

The stem dry mass is a variable influenced by the height of the tree because of its direct relation with the structure of the plant, where its participation in the proportion of the morphological components is influenced by the height and age of the grass. The production of DMS and DSM per cycle followed the same pattern regardless of the period, with the linear pattern increasing according to the elevation of cutting height for both evaluated systems. The monoculture system had the highest accumulation of DMS and DSM per cycle with $110.7 \mathrm{~kg}$ of DMS per cycle and $44.6 \mathrm{~kg}$ DSM per cycle in the rainy period for each $10 \mathrm{~cm}$ that was added at the time of cutting. In SSP, the DMS per cycle was $45.5 \mathrm{~kg}$ and the DSM per cycle was $4.61 \mathrm{~kg}$ for every $10 \mathrm{~cm}$ increased at the time of cut for the same period. Rodrigues et al. (2016), when assessing different heights of management in SSP, verified that the variation of morphological components such as stalk and senescent material does not tend to suffer significant increases, whereas in the leaf/stem ratio as the height of harvest increases there is higher leaf proportion regardless of the cutting height. 
Table 5. Percentage of MS of Mombasa grass in silvopastoral and monoculture systems at different times of the year

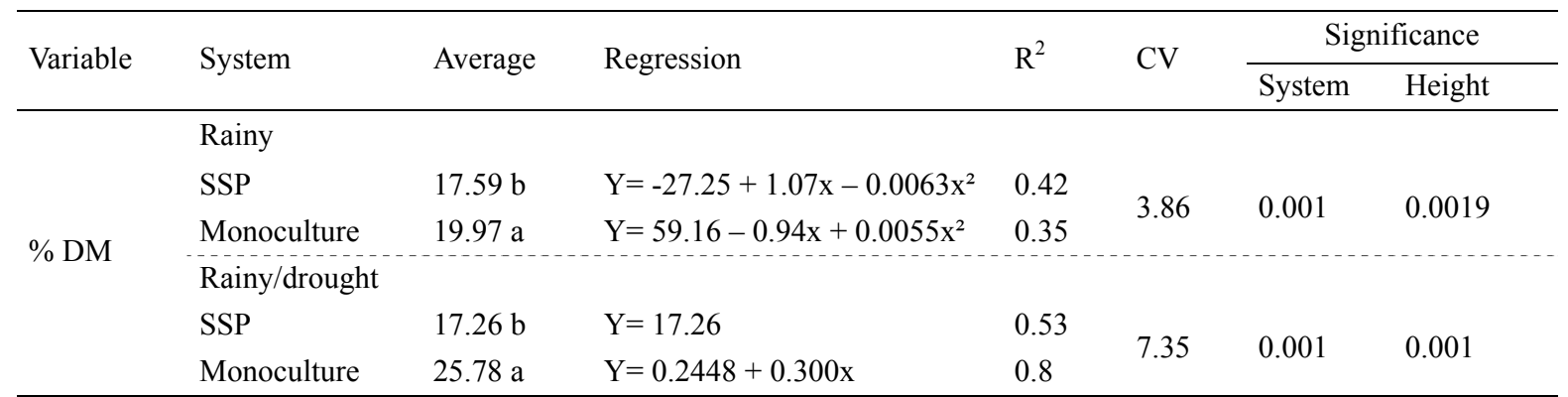

Note. Lowercase letters compare systems by the Duncan's test at 5\% probability. Percentage of dry mass (\% DM), coefficient of variation $(\mathrm{CV})$.

In the transition period DMS and DSM per cycle in the monoculture system were 71.31 and $278.4 \mathrm{~kg}$, respectively, for each $10 \mathrm{~cm}$ of cutting height increase. As for SSP, the productions of DMS and DSM per cycle were 75.6 and $27.4 \mathrm{~kg}$. The increase in cutting height increases the resting period, which tends to result in higher accumulations of stalk and senescent material, affecting the quality of accumulated DM (Barbosa et al., 2007).

The production of senescent material has a direct correlation with the management height and the age of the plant, and its proportion tends to increase as the plant reaches maturity and approaching the reproduction phase. The presence of senescent material is one of the factors that can raise the DM content. The amount of DSM increased during the rainy/drought transition period due to the decrease of precipitation and the approximation of the grass of its reproduction period. The highest heights presented higher DSM production. The increase in cutting height may directly influence the production of morphological components such as stalk and senescent material, as well as increase the period of intervals between one harvest and another, causing the grass structure to change, affecting the quality of DM (Barbosa et al., 2007).

The monoculture system had the highest DM contents when compared to the SSP. SSP had a quadratic effect with maximum point around $84.9 \mathrm{~cm}$ in height. The monoculture system also presented a quadratic effect for the rainy season with a minimum point of $85.4 \mathrm{~cm}$ in height. In the rainy/drought transition period, the SSP had no effect, where the levels did not vary regardless of the cutting height. In the monoculture system there was a linear increase, increasing by $3 \%$ every $10 \mathrm{~cm}$ added at the time of cutting. The DM content tends to increase as grass management height and plant age increase, but the quality of its composition tends to decrease with increasing height and age. Its quality is directly influenced by the leaf/stem ratio and also by the amount of senescent material. The same was reported by Souza et al. (2007), who verified that shading significantly affects the DM content of the forage under shading conditions due to a higher proportion of leaves. According to Gobbi et al. (2011), another factor that reduces the DM content of the grass in a shading system is the modification in the leaf anatomy, with a reduction of the sclerenchymatic tissues and the thickness of the palisade parenchyma.

\section{Conclusions}

Management height, type of system and time of year influenced the productivity of Mombasa grass. The production patterns of the morphological components leaf, stem, and senescent material of Mombasa grass in the silvopastoral system followed the same patterns of the monoculture system.

In the monoculture system, the recommended height aiming for a higher TDM productivity and a greater leaf/stem ratio in the rainy season and in the rainy/drought transition is the cutting management strategy at $80 \mathrm{~cm}$ in height, maintaining the residue height of $40 \mathrm{~cm}$. In SSP, the cutting height of $70 \mathrm{~cm}$ presented the highest TDM and leaf/stem ratio for both evaluated periods, maintaining the height of $40 \mathrm{~cm}$.

\section{References}

Almeida, J. C. C., Rocha, N. S., Nepomuceno, D. D., Araújo, R. P., Silva, T. O., Morentz, M. J. F., Abreu, J. B. R., Carvalho, C. A. B., \& Macedo, R. O. (2015). Composição mineral de leguminosas forrageiras cultivadas sob diferentes níveis de sombreamento. Semina: Ciências Agrárias, 36(1), 367-376. https://doi.org/10.5433/ 1679-0359.2015v36n1p367 
Andrade, C. M. S., Garcia, R., Couto, L., Pereira, O. G., \& Souza, A. L. (2003). Desempenho de Seis Gramíneas Solteiras ou Consorciadas com o Stylosanthes guianensis cv. Mineirão e Eucalipto em Sistema Silvipastoril. Revista Brasileira de Zootecnia, 32(6), 1845-1850. https://doi.org/10.1590/S1516-35982003000800006

Andrade, C. M. S., Valentim, J. F., Carneiro, J. C., \& Vaz, F. V. (2004). Crescimento de gramíneas e leguminosas forrageiras tropicais sob sombreamento. Pesquisa Agropecuária Brasileira, 39(3), 263-270. https://doi.org/ 10.1590/S0100-204X2004000300009

Barbosa, R. A., Nascimento Junior, D., Euclides, V. P. B., Silva, S. C., Zimmer, A. H., \& Torres Junior, R. A. A. (2007). Capim-tanzânia submetido a combinações entre intensidade e frequência de pastejo. Pesquisa Agropecuária Brasileira, 42(3), 329-340.

Belesky, D. P. (2005). Growth of Dactylis glomerata along a light gradient in the central Appalachian region of the eastern USA: I. Dry matter production and partitioning. Agroforestry Systems, 65(2), 81-90. https://doi.org/10.1007/s10457-004-5725-y

Brossard, M., \& Barcellos, A. O. (2005). Conversão do cerrado em pastagens cultivadas e funcionamento de latossolos. Revista Cadernos de Ciência \& Tecnologia, 22(1), 153-168.

Carvalho, M. M., Freitas, V. P., \& Xavier, D. F. (2002). Inicio de florescimento, produção e valor nutritivo de gramíneas tropicais sob condições de sombreamento natural. Revista de Pesquisa Agropecuária Brasileira, 37(5), 717-722. https://doi.org/10.1590/S0100-204X2002000500018

Castro, C. R. T., Garcia, R., Carvalho, M. M., \& Freitas, V. P. (2001). Efeitos do Sombreamento na Composição Mineral de Gramíneas Forrageiras Tropicais. Revista Brasileira de Zootecnia, 30, 1959-1968. https://doi.org/10.1590/S1516-35982001000800001

Dias-Filho, M. B. (2000). Growth and biomass allocation of the c grasses Brachiaria brizantha and B. humidicola under shade. Pesquisa Agropecuária Brasileira, 35(12), 2335-2341. https://doi.org/10.1590/ S0100- 204X2000001200003

Gobbi, K. F., Garcia, R., Garcez-Neto, A. F., Pereira, O. G., Ventrella, M. C., \& Rocha, G. C. (2009). Características morfológicas, estruturais e produtividade docapim braquiária e do amendoim forrageiro submetidos ao sombreamento. Revista Brasileira de Zootecnia, 38(9), 1645-1654. https://doi.org/10.1590/ S1516-35982009000900002

Gobbi, K. F., Garcia, R., Ventrella, M. C., Garcez Neto, A. F., \& Rocha, G. C. (2011). Área foliar específica e anatomia foliar quantitativa do capim-braquiária e do amendoim-forrageiro submetidos a sombreamento. Revista Brasileira Zootecnia, 40(7), 1436-1444. https://doi.org/10.1590/S1516-35982011000700006

Oliveira, L. B. T., Santos, A. C., André, T. B., Santos, J. G. D., \& Oliveira, H. M. R. (2017). Influence of a silvopastoral system on anatomical aspects and dry matter qualitty of Mombasa and Marandu grasses. Journal of Agriculture and Ecology International, 13(3), 1-11. https://doi.org/10.9734/JAERI/2017/31624

Oliveira, L. B. T., Santos, A. C., Oliveira, H. M. R., André, T. B., Neves, D. N., \& Silveira Júnior, O. (2018). Characteristics and classification of the quality and productive standards of the mombaça grass under a livestock-forest system or full sun. Semina: Ciências Agrárias, 39(4), 1447-1458. https://doi.org/10.5433/ 1679-0359.2018v39n4p1447

Oliveira, T. K., Macedo, R. L. G., Santos, I. P. A., Higashikawa, E. M., \& Venturina, N. (2007). Produtividade de brachiaria brizantha (Hochst. ex a. Rich.) stapf cv. marandu sob diferentes arranjos estruturais de sistema agrossilvipastoril com eucalipto. Revista Ciência Agrotécnologia, 31(3), 748-757. https://doi.org/10.1590/ S1413-70542007000300022

Paciullo, D. S. C., Campos, N. R., Gomide, C. A. M., Castro, C. R. T., Tavela, R. C., \& Rossiello, R. O. P. (2008). Crescimento de capim-braquiária influenciado pelo grau de sombreamento e pela estação do ano. Pesquisa Agropecuária Brasileira, 43(7), 917-923. https://doi.org/10.1590/S0100-204X2008000700017

Paciullo, D. S. C., Carvalho, C. A. B., Aroeira, L. J. M., Morenz, M. J. F., Lopes, F. C. F., \& Rossiello, R. O. P. (2007). Morfofisiologia e valor nutritivo do capim-braquiária sob sombreamento natural e a sol pleno. Pesquisa Agropecuária Brasileira, 42(4), 573-579. https://doi.org/10.1590/S0100-204X2007000400016

Paciullo, D. S. C., Gomide, C. A. M., Castro, C. R. T., Fernandes, P. B., Muller, M. D., Pires, M. F. A., ... Xavier, D. F. (2011). Características produtivas e nutricionais do pasto em sistema agrossilvipastoril, conforme a distância das arvores. Pesquisa Agropecuária Brasileira, 46(10), 1176-1183. https://doi.org/10.1590/S0100204X2011001000009 
Rodrigues, M. O D., Santos, A. C., Santos, P. M., Souza, J. T. L., Alexandrino, E., \& Santos, G. D. (2016). Caracterização do capim Mombaça em diferentes alturas de pastejo em sistema de consorcio com babaçu e monocultivo. Revista Semina: Ciências Agrárias, 37(4), 2085-2098. https://doi.org/10.5433/1679-0359. 2016v37n4p2085

Santos, P. M., Balsalobre, M. A. A., \& Corsi, M. (2004). Características Morfogenéticas e Taxa de Acúmulo de Forragem do Capim-Mombaça Submetido a Três Intervalos de Pastejo. Revista Brasileira de Zootecnia, 33(4), 843-851. https://doi.org/10.1590/S1516-35982004000400004

Soares, A. B., Sartor, L. R., Adami, P. F., Varella, A. C., Fonseca, L., \& Mezzalira, J. C. (2009). Influência da luminosidade no comportamento de onze espécies forrageiras perenes de verão. Revista Brasileira de Zootecnia, 38(3), 443-451. https://doi.org/10.1590/S1516-35982009000300007

Souza, L. F., Mauricio, R. M., Goncalves, L. C., Saliba, E. O. S., \& Moreira, G. R. (2007). Produtividade e valor nutritivo da Brachiaria brizantha cv. Marandu em um sistema Silvipastoril. Revista Arquivos Brasileiros de Medicina Veterinária e Zootecnia, 59(4), 1029-1037. https://doi.org/10.1590/S0102-09352007000400032

Santos, P. M., Santos, A. C., Neves Neto, D. N., Oliveira, W. H., Sousa, L. F., \& Oliveira, L. B. T. (2018). Implementation of silvopastoral systems under nutrient cycling in secondary vegetation in the Amazon. Journal of Agricultural Science, 10(4). https://doi.org/10.5539/jas.v10n4p124

\section{Copyrights}

Copyright for this article is retained by the author(s), with first publication rights granted to the journal.

This is an open-access article distributed under the terms and conditions of the Creative Commons Attribution license (http://creativecommons.org/licenses/by/4.0/). 